\title{
Special issue on "The role of intellectual capital and integrated reporting in management and governance: a performative perspective"
}

\author{
Stefano Zambon ${ }^{1} \cdot$ Stefano Marasca ${ }^{2} \cdot$ Maria Serena Chiucchi $^{2}$
}

Published online: 22 May 2019

(c) Springer Science+Business Media, LLC, part of Springer Nature 2019

\section{Aims and scope of the special issue}

The measurement, reporting and management of Intangibles and Intellectual Capital (IC) at a micro, meso and macro level is becoming a focal topic for the theory and practice of various disciplines (financial and management accounting, valuation, marketing, organisation behaviour, strategy, non-financial reporting, investor relations, human resources, sustainability, etc.) (Guthrie et al. 2012). More recently, the debate has been further energized by the Integrated Reporting initiative, whose focus on the value creation processes has revealed new research and practical perspectives on the complex and multifaceted role of Intangibles and Intellectual Capital in the management and governance of organizations with respect to internal and external actors (de Villiers et al. 2014, 2019 Special Issue of Journal of Intellectual Capital).

Whilst it is possible to identify several attempts to define what IC is and how organizations should report on it through IC Statements or Integrated Reporting (so called "ostensive dimension") (Edvinsson and Malone 1997; Lev 2001; Sveiby 1997; WICI 2016), less effort has been made to understand the IC performative dimension and its implications for organizations and their context, as well as for the theoretical aspects of this subject area (Catasús et al. 2007; Catasús and Gröjer 2006; Mouritsen 2006). In fact, in order to investigate the external, social, and organizational effects of IC Statements and Integrated Reporting, several scholars have highlighted the need to abandon the extant "grand theories", and to adopt a

Maria Serena Chiucchi

m.s.chiucchi@univpm.it

Stefano Zambon

zmbsfn@unife.it

Stefano Marasca

s.marasca@univpm.it

1 University of Ferrara, Ferrara, Italy

2 Università Politecnica delle Marche, Ancona, Italy 
practice-based lens of analysis (Stubbs and Higgins 2014; Churet and Eccles 2014; Dumay 2012; Dumay and Garanina 2013; Lodhia 2015; Chiucchi 2013).

Adopting a performative approach in IC research means in the first instance investigating — with a bottom-up approach — what IC does and how IC is understood and implemented in practice, especially shedding light on what happens in the multifaceted dimensions of governance and management, where IC is concretely measured, visualised and dealt with (Dumay 2012, 2014; Guthrie et al. 2012; Mouritsen 2006; O'Donnell et al. 2006). Yet, the conceptual, multidisciplinary and the wider contextual consequences of performing and experimenting Intangibles and IC in organizations are also of interest to this approach (Zambon 2016).

Finally, it is important to highlight the relevance that corporate governance has on the management, measurement and development of IC. Internal mechanisms of corporate governance refer to how organizational structures and procedures can direct managerial and board attention and behaviour towards issues of increasing the wealth of a firm. In this case, the focus is on how the company governance may be supported to take care of Intangibles and IC in all their nuances, by considering the criticalities and opportunities associated with their management, by understanding how the actors involved in their creation and development process behave and how this behaviour can be influenced in order to improve corporate performance. More specifically, attention has been directed to the relationships between Intangibles and IC performance and board systems, executive compensation models, etc. (AlMusali and Ismail 2015; Nicholson and Kiel 2004; Swartz and Firer 2005). External mechanisms of corporate governance can be related to the ideas of accountability and transparency towards shareholders and stakeholders. The reference here is to the above mentioned reporting models, the elements that affect Intangibles and IC disclosure and the effects of Intangibles and IC disclosure (Al-Musalli and Ismail 2012; Cerbioni and Parbonetti 2007; Li et al. 2008; Nicholson and Kiel 2004; Saeed et al. 2014; Williams 2001). By governing these external mechanisms, managers may obtain legitimization and try to achieve a positive evaluation of the corporate performance by the capital market actors.

This Special Issue aims to explore how Intangibles, Intellectual Capital and Integrated Reporting affects the management and governance of organizations and users' behaviours by focusing on the empirics of practice, cases, and experiences.

\section{The papers}

The Special Issue is grounded on the papers presented at the $13^{\text {th }}$ EIASM Interdisciplinary Workshop on "Intangibles and Intellectual Capital-Value Creation, Integrated Reporting and Governance" held at Università Politecnica delle Marche in Ancona (Italy) on 21-22 September 2017 (for details on the conference see: www. eiasm.org/frontoffice/event_announcement.asp?event_id=1243). This is the 2017 workshop of the most important continuing series of annual academic events in Europe in the above subject area since 2005, and it has nowadays reached a widespread visibility in the scholarly as well as-to some extent- the professional and institutional community. 
All the works published in the present Special Issue have been subject to a lengthy double-blind review process and revised quite largely before their acceptance for publication.

The papers selected provide insightful views on what is the today's state-of-theart of the research on intangibles and related topics and issues. In detail, four of them deal with different aspects of intangibles disclosure, and the other four with the identification, management and use of IC and IC reporting. Interestingly to note, all the papers have employed qualitative methodologies, such as field studies and interviews.

The paper titled "Integrated reporting in action: mobilizing intellectual capital to improve management and governance practices" by Francesco Badia, Grazia Dicuonzo, Saverio Petruzzelli and Vittorio Dell'Atti (University of Bari) has tried to answer two questions about (a) the possibilities for integrated reporting to increase the awareness of intellectual capital (IC) to improve management and governance practices and, (b) the business conditions that can influence the processes related to integrated reporting and therefore, intellectual capital. Three companies that are in the 'integrated journey' and operate in different industries have been investigated. The paper has demonstrated that for all of them the implementation of integrated reporting has revealed to be a valuable way through which mobilizing and creating awareness of intellectual capital. With reference to the business conditions that can influence the understanding of the significance of IC, three have been found of particular relevance, being the listing on financial markets, the size of the company and the ownership structure.

The primary purpose of the paper "A Performative Exploration of the Lifeworlds of Human Capital and Financial Capital: An Intellectual Capital Case Vignette" by Sandra Brosnan (University College Cork), David O’Donnell (Intellectual Capital Research, Limerick) and Philip O'Regan (University of Limerick) is to illustrate how one particular relationist/realist ontological approach to performative research, with a focus on professionals' (HR and finance leaders) subjective interpretations of intangibles/intellectual capital, may be capable of generating reasonably substantive findings. It results that value orientations towards intangibles/intellectual capital are clearly present in the human resource (human capital) profession; what is striking is their apparent absence in the finance/accounting (financial capital) profession as the phenomenon may be perceived by the latter to lack professional accounting legitimacy.

The paper "Is There a Need to Implement Integrated Reporting in Healthcare? A Performative Case Study" by Caterina Cavicchi, Chiara Oppi and Emidia Vagnoni (University of Ferrara) aims to investigate the mechanisms that affect the possible development of integrated reporting (IR) practices in the healthcare sector. It discusses the process of construction, production, and consumption of the management commentary in a university hospital. Findings with both the report's preparers and institutional users show that the management commentary is conceived as mainly addressing normative requirements, thus resulting in a heavy document stemming from the preparers' silo mentality, with very limited usefulness for its users. Users reported that the management commentary could be meaningful if it arose from a shared planning process emphasizing the connectivity of the university hospital's 
activities with the local stakeholders' activities. This latter assertion, however, is not shared by the organization's top management.

The paper on "Concepts travelling across disciplinary fields: the case of the business model" by Laura Girella (International Integrated Reporting Council), Roberto Tizzano (University of Naples "Federico II") and Elisa Rita Ferrari (Kore University of Enna) has examined how the concept of business model has moved across different disciplinary arenas, from the strategy field to the financial and non-financial reporting fields, in order to reveal the similarities and differences that characterise their attitudes towards the adoption of this concept. The findings support the view that the three arenas have reacted to the adoption of this concept differently, even though some analogies can be observed. Indeed, both the strategy and the non-financial reporting fields have found to be quite open and inclusive towards the adoption of this concept. On the contrary, the rigid and parochialistic nature of the financial reporting, and in general the accounting arena, has led to a "resistance to change" behaviour.

In relying on the premise that to date the relevance of specific actors in influencing the adoption of IC Reports seems to be an overlooked topic, the paper "Guess who's coming to dinner: the case of IC reporting in Italy" by Marco Giuliani and Maria Serena Chiucchi (Università Politecnica delle Marche) investigates which are the organizational and external actors that can influence the uptake and the fate of an IC report and the manners in which they influence these reports. Evidence suggests that political, technical, and cultural agents, i.e. the project leaders, the project sponsors and the external partners (consultants, researchers, etc.), are not only relevant but they must coexist and cooperate over time, despite their different roles. In particular, the external partner introduces the concept and the technology of IC report, the project sponsor results to be the agent that instil the need for change within the organization and the project leader operationalize the change.

The work "The management of participatory cultural initiatives: learning from the discourse on intellectual capital" by Martin Piber (University of Innsbruck), Paola Demartini (University of Rome Three) and Lucia Biondi (University of Rome Three) addresses how it is possible through the adoption of an IC lens to understand, assess and communicate the impact that Participatory Cultural Initiatives (PCIs) have on their stakeholders. In doing so, the investigation focuses on two PCIs in Italy: Big City Life, a street art district in Tor Marancia (Rome) and the project of Matera as European Capital of Culture 2019. Evidence shows that narratives and visualisations play a crucial role by supporting comprehension of the PCIs' key aspects and their interwoven relations. A condition for narratives and visualisations to be accepted as legitimation tools is the development of a trust relationship among stakeholders.

The research "Integrated reporting and the performativity of intellectual capital" by Silvano Corbella, Cristina Florio, Alice Francesca Sproviero and Riccardo Stacchezzini (University of Verona) investigates how IC is problematised in the context of integrated reporting. It explores the role of organizational actors in defining, classifying and valuing IC within the process of preparing an integrated report. The analysis reveals that IC definition, classification and valuation stimulate ongoing interaction among various actors. An active role is played by the staff of the 
department responsible for the IR preparation process, but also by organisational actors who are not directly involved in this process and by external actors, such as the company's peers, IIRC representatives and the company's accounting advisors. Some sketches, matrixes and maps inspired by the IIRC Framework were pivotal in defining concepts and categories of IC and its connection to value creation, although the quantification of IC's effect on value creation remains disputed.

\section{Conclusive remarks}

Intangibles, IC and Integrated Reporting in their interactions give rise to a clearly vibrant area for scientific research and progress today and tomorrow. The performative perspective here adopted, in its intertwining with the theoretical realm, provides an incredibly rich standpoint from which to look at the concrete effects and issues of managing, visualizing and reporting on intangibles in an integrated mode.

Leaving aside an ostensive approach in favour of a performative inquiry permits to researchers to give "body and soul" to the concepts of intangibles and intellectual capital and their role of drivers of the organizational becoming and growth, which should find a natural representation in integrated reporting.

The papers that compose the Special issue provide an acute and widespread illustration of the above conclusion. By highlighting and analysing in variegated and to some extent unexpected contexts the practical - and also the problematic-side of both concepts, such as that of intellectual capital or business model, and tools, such as that of integrated reporting, the papers reveal that these are often referred to or used as an outcome of a fad rather than of an understanding of their concrete impacts and implications for organizations' life and governance. Far from being "pasteurized" and neutral, those concepts and tools are infused of and affected by, but also condition and influence, organizational and personal values, being embedded in contextual dynamics, and they find distinct connotations, usages and interpretations in various settings, which can be explored using diversified methodological and even philosophical approaches (e.g. Habermasian frames employed in two papers).

Therefore, what emerges from the works here presented appears to give "flesh, blood and legs" to theoretical or high-level artifacts that otherwise risk remaining some empty and fashionable semantic containers, thus paving the way to future promising research avenues.

Acknowledgements We would like to thank the Editor-in-Chief of the Journal, Prof. Lino Cinquini, for believing in the initiative and his patience and support to foster and follow the process. A grateful thought goes also to the EIASM that provided the scientific occasion and context for preparing and presenting the papers forming the present Special Issue.

\section{References}

Al-Musali, M. A. K. M., \& Ismail, K. N. I. K. (2015). Board diversity and intellectual capital performance: The moderating role of the effectiveness of board meetings. Accounting Research Journal, 28(3), 268-283. 
Al-Musalli, M. A. K., \& Ismail, K. N. I. K. (2012). Corporate governance, bank specific characteristics, banking industry characteristics, and intellectual capital (IC) performance of banks in arab gulf cooperation council (GCC) countries. Asian Academy of Management Journal of Accounting \& Finance, $8(1), 115-135$.

Catasús, B., Ersson, S., Gröjer, J. E., \& Wallentin, F. Y. (2007). What gets measured gets ... on indicating, mobilizing and acting. Accounting, Auditing \& Accountability Journal, 20(4), 505-521.

Catasús, B., \& Gröjer, J. E. (2006). Indicators: On visualizing, classifying and dramatizing. Journal of Intellectual Capital, 7(2), 187-203.

Cerbioni, F., \& Parbonetti, A. (2007). Exploring the effects of corporate governance on intellectual capital disclosure: An analysis of European biotechnology companies. European Accounting Review, 16(4), 791-826.

Chiucchi, M. S. (2013). Intellectual capital accounting in action: Enhancing learning through interventionist research. Journal of Intellectual Capital, 14(1), 48-68.

Churet, C., \& Eccles, R. G. (2014). Integrated reporting, quality of management, and financial performance. Journal of Applied Corporate Finance, 26(1), 56-64.

de Villiers, C., Rinaldi, L., \& Unerman, J. (2014). Integrated reporting: Insights, gaps and an agenda for future research. Accounting, Auditing \& Accountability Journal, 27(7), 1042-1067.

Dumay, J. (2012). Grand theories as barriers to using IC concepts. Journal of Intellectual Capital, $13(1), 4-15$.

Dumay, J. (2014). Reflections on interdisciplinary accounting research: The state of the art of intellectual capital. Accounting, Auditing \& Accountability Journal, 27(8), 1257-1264.

Dumay, J., \& Garanina, T. (2013). Intellectual capital research: A critical examination of the third stage. Journal of Intellectual Capital, 14(1), 10-25.

Edvinsson, L., \& Malone, M. S. (1997). Intellectual capital. New York: Harper Business.

Guthrie, J., Ricceri, F., \& Dumay, J. (2012). Reflections and projections: A decade of intellectual capital accounting research. British Accounting Review, 44(2), 68-82.

Lev, B. (2001). Intangibles: Management, measurement and reporting. Washington, DC: Brookings Institution Press.

Li, J., Pike, R., \& Haniffa, R. (2008). Intellectual capital disclosure and corporate governance structure in UK firms. Accounting and Business Research, 38(2), 137-159.

Lodhia, S. (2015). Exploring the transition to integrated reporting through a practice lens: An Australian customer owned bank perspective. Journal of Business Ethics, 129(3), 585-598.

Mouritsen, J. (2006). Problematising intellectual capital research: Ostensive versus performative IC. Journal of Intellectual Capital, 19(6), 820-841.

Nicholson, G. J., \& Kiel, G. C. (2004). Breakthrough board performance: How to harness your board's intellectual capital. Corporate Governance: The international journal of business in society, 4(1), 5-23.

O’Donnell, D., Bo Henriksen, L., Voelpel, S. C., O’Donnell, D., Bo Henriksen, L., \& Voelpel, S. C. (2006). Guest editorial: Becoming critical on intellectual capital. Journal of Intellectual Capital, 7(1), 5-11.

Saeed, S., Rasid, S., \& Basiruddin, R. (2014). Impact of corporate governance on corporate performance through intellectual capital. In F. L. Gaol, S. Kadry, M. Taylor, \& P. Shen Li (Eds.), Recent trends in social and behaviour sciences: Proceedings of the international congress on interdisciplinary behaviour and social sciences 2013 (pp. 191-196). Boca Raton: CRC Press.

Stubbs, W., \& Higgins, C. (2014). Integrated reporting and internal mechanisms of change. Accounting, Auditing \& Accountability Journal, 27(7), 1068-1089.

Sveiby, K. E. (1997). The intangible assets monitor. Journal of Human Resource Costing \& Accounting, 2(1), 73-97.

Swartz, N., \& Firer, S. (2005). Board structure and intellectual capital performance in South Africa. Meditari Accountancy Research, 13(2), 145-166.

WICI. (2016). WICI intangibles reporting framework-version 1.0, September. www.wici-globa 1.com.

Williams, S. M. (2001). Corporate governance diversity and its impact on intellectual capital performance in an emerging economy. Calgary: University of Calgary, Faculty of Management.

Zambon, S. (2016). Ten years after: The past, the present and the future of scholarly investigation on intangibles and intellectual capital. Journal of Intellectual Capital, 17(1), 2-10. 
Publisher's Note Springer Nature remains neutral with regard to jurisdictional claims in published maps and institutional affiliations.

Stefano Zambon (PhD, London) is Full Professor of Accounting and Business Economics at the University of Ferrara, Italy. Visiting appointments in universities of four continents, including Waseda School of Management, Stern Business School (NYU), London Business School, and HEC, CNAM and ESCP in Paris. Since 2005, he is the coordinator of the EIASM Conference series on "Intangibles and Intellectual Capital". Invited keynote speaker at OECD, United Nations, European Parliament, European Commission, and French, Chinese and Japanese Governments' events on intangibles. A founding member of the Global Network "World Intellectual Capital Initiative" - WICI, of which he is the Chair since July 2015. From 2014 to 2018, President of the official Expert Group on Intangibles set up by the French Government.

Stefano Marasca is Full Professor of Business Administration at Università Politecnica delle Marche, in Ancona, Italy, where he teaches Strategic Control Systems in graduate, undergraduate and PHD courses. His research interests include corporate strategy, intellectual capital, management control, management accounting and intangible and firm evaluation. He has conducted many interventionist research projects in private and public organizations regarding Business Planning, Control Systems, Intellectual Capital and Integrated Reporting. He is a member of the Editorial Board of the journal "Management Control" and of other journals and Editor of a Book Series officially recognized by SIDREA, the Italian Association of Scholars in Accounting and Business Administration. He is the author of articles on intangibles, intellectual capital, financial reporting, integrated reporting and on strategy and management control, in profit and non profit organisations, published in international and national peer reviewed journals. He has also authored books and book chapters on the same themes.

Maria Serena Chiucchi is Full Professor of Business Administration at Università Politecnica delle Marche, in Ancona, Italy where she teaches Management Accounting and Financial Reporting in graduate and undergraduate courses. Her research interests include intellectual capital, management control, management accountant and qualitative research with particular reference to the case study method. In addition, over the last ten years, she has been conducting several interventionist research projects regarding management accounting and Intellectual Capital and more recently Integrated Reporting. She is the Co-Editor of the journal "Management Control" and Associate Editor of the "Electronic Journal of Knowledge Management". She is the author of articles on management control, on intangibles, intellectual capital and on case study research published in international and national peer reviewed journals. She has also authored books and book chapters on the same themes. 